\title{
What's Love Got to Do with It? Religion and the Multiple Logic Tensions of Social Enterprise
}

\author{
Bruce R. Borquist $(D$
}

check for updates

Citation: Borquist, Bruce R. 2021 What's Love Got to Do with It? Religion and the Multiple Logic Tensions of Social Enterprise. Religions 12: 655. https://doi.org/ $10.3390 /$ rel12080655

Academic Editors: Steven Rundle and Min-Dong (Paul) Lee

Received: 1 July 2021

Accepted: 12 August 2021

Published: 18 August 2021

Publisher's Note: MDPI stays neutral with regard to jurisdictional claims in published maps and institutional affiliations.

Copyright: (C) 2021 by the author. Licensee MDPI, Basel, Switzerland. This article is an open access article distributed under the terms and conditions of the Creative Commons Attribution (CC BY) license (https:/ / creativecommons.org/licenses/by/ $4.0 /)$.
International Ministries_ABCUSA, King of Prussia, PA 19406, USA; bruce.borquist@koinos.me

\begin{abstract}
This paper develops a model that advances our understanding of how social enterprises respond to the complexity of a constellation of multiple, often competing goals, referred to here as institutional logics. Introducing a religious logic to the recognised social welfare and commercial logics of social enterprise, this model builds on a religious worldview foundation and incorporates religion-inspired altruistic love and non-transactional giving as its scaffolding. A comparative case study of faith-based, faith-inspired and secular organisations located in Southeast Asia demonstrates the origin and applicability of the model. Findings highlight that religion serves as an overarching logic, or "metalogic", and frame of reference. Faith-based social enterprises use this religious logic to redefine perceived paradoxical tensions between the social welfare and commercial objectives they embody. Study results advance knowledge on organisational responses to multiple logic prescriptions, underscores the influence of religion, altruistic love and giving on organisational behaviour and contributes to the scarce literature on faith-based social enterprises.
\end{abstract}

Keywords: faith-based social entrepreneurship; institutional logics; inter-logic tensions; framing; religion; hybrid organisations

\section{Introduction}

Faith-based social enterprises offer an opportunity to develop new insights into how organisations respond to tensions created by contrasting prescriptions of the multiple goals, or institutional logics, they incorporate. Institutional logics are the socially constructed, unwritten "rules of the game" (Ocasio 1997, p. 196) that organise and define organisational and individual behaviour. Empirical studies that explore the characteristics of faith-based social enterprises and social entrepreneurial faith-based organisations (FBOs) are rare (Alderson 2011; Borquist 2020; Oham 2015; Rundle 2014). Even fewer have employed the perspective of institutional logics, except for a handful of noteworthy studies (Grass1 2011; Gümüsay 2020; Roundy et al. 2016; Zhao and Lounsbury 2016). This lack of research is striking since FBOs have made and continue to make, significant contributions toward meeting human needs and addressing challenging social problems (Göçmen 2013).

This paper addresses significant research gaps by focusing on social entrepreneurial FBOs in a Christian religious faith context. The phrase 'faith-based' presents significant definitional challenges when applied to organisations, as 'faith' can have various meanings depending on its usage (Miller 2003). Religious faith is understood as a form of spirituality based on a codified set of moral values, beliefs and doctrines shared by a group and expressed through activities and institutions (King 2007; Stark 1996). Drawing upon Berger (2003) and Crisp (2014), I adopt a straightforward working definition that FBOs are organisations whose identity and mission are explicitly derived from the teachings of one or more religious or spiritual traditions. Thus, I define a social entrepreneurial organisation as 'faith-based' when religious faith, values and a religious worldview are central and determinative to its conceptualisation, operation and evaluation.

Guided by the research question 'How does a religious logic influence the ways social enterprises experience and manage tensions created by their multiple institutional logics?', 
I conducted a comparative multiple case study of faith-based, faith-inspired and secular organisations. 'Little narratives' (Bull and Ridley-Duff 2019) of these organisations offer new insights into how social entrepreneurial organisations and their members manage paradoxical tensions between their ultimate goals.

Social entrepreneurial FBOs demonstrate that a religious logic derived from a worldview shaped by religious faith may influence how organisations experience and respond to paradoxical logic tensions. An empirically derived model proposes that a worldview derived from religious faith informs a religious "metalogic" that faith-based social enterprises employ to respond to tension between their social welfare and commercial logics. Further, the data suggest that organisational actors (re-)frame their relationship with the logic tensions they experience by interpreting conflicting social welfare and commercial logic prescriptions in light of a religious metalogic's mandates to engage in acts of altruistic caritas love and non-transactional gift giving.

This study's contribution to cumulative knowledge on how organisations experience and manage tensions created by the multiple logic prescriptions they embody is threefold. First, the investigation responds to recent calls to investigate the influence of religion on entrepreneurial behaviour (Smith et al. 2019, 2021). Study results suggest that the hybrid nature of social enterprises is based on other-regarding values rooted in a religious worldview, as revealed explicitly in social entrepreneurial FBOs. Second, findings and conclusions contribute to theory building on the institutional logic of religion and how organisations use a religious metalogic to frame and thereby manage paradoxical inter-logic tensions. The research advances an alternative view of responses to institutional complexity by arguing that social enterprises transcend the paradoxical prescriptions of social welfare and commercial logics by framing these goals in terms of non-transactional giving motivated by altruistic caritas love. Third, and finally, the various elements of this argument are neatly encapsulated in a values-based, contextually embedded model that lends itself to future testing and research on how social enterprises address institutional complexity (de Bruin and Teasdale 2019). In sum, this model and the study's empirical findings offer a more nuanced view of organisational responses to the paradoxical prescriptions of multiple institutional logics and illuminate the influence of a religious worldview and logic on social enterprises.

The paper proceeds by establishing the theoretical background for the research. Next, I outline the research methodology and present my findings. A discussion of implications for knowledge and theory building about social enterprises and institutional theory follows. I conclude by reviewing limitations and future research directions.

\section{Theoretical Background}

\subsection{Social Enterprise}

Faith-based entrepreneurs and organisations have a long history of contributing to positive social change through initiatives that create social benefit through commercial means (Cnaan 1999; Dana 2009). Entrepreneurs Guinness and Cadbury in 18th and 19th century England explicitly integrated Christian religious faith, social engagement and commercial enterprise (Dodd and Seaman 1998). Prominent Christian FBOs such as the Salvation Army and the Society of St. Vincent de Paul have mixed social engagement and commercial enterprise since their founding (Berger 2003; Bowes 1998; Magnuson 1977). In the mid-20th century, Roman Catholic priest Father José María Arizmendiarrieta Madariaga created the Mondragón Cooperative Corporation in Spain, a successful federation of worker-owned cooperatives that blends faith-based values of social solidarity with cooperative business principles (Spear 2010). These FBOs that engaged in meeting human needs and addressing social problems through entrepreneurial means in the 18th, 19th and early 20th centuries can be regarded as the predecessors of modern social enterprises (Baglioni 2017; Spear 2010). Today, social enterprises address 'wicked problems' in society such as poverty, social exclusion and environmental degradation (Dorado and Ventresca 2013). 
Scholars, practitioners and governments continue to propose and debate definitions for what constitutes a social enterprise. Based on extant literature, I define a social enterprise as a hybrid organisation that responds to neglected social (including environmental) problems by integrating social welfare and commercial goals to create positive social change through initiatives that prioritise social value creation over economic value capture (Doherty et al. 2014; Santos 2012; Stephan et al. 2016).

Reflecting its hybrid nature, the academic and practice-based discourse on social enterprise is also a hybrid. As can be noted throughout the paper, the social enterprise narrative blends the language of social action and positive social change with that of commercial entrepreneurship. The observation that social enterprises can be regarded as a form of economic hybridity (Yang 2000) has been celebrated and criticised. Advocates argue that the phenomenon of social entrepreneurship reflects societal disenchantment with unrestrained entrepreneurial capitalism and challenges the dominant liberal economic paradigm (de Bruin et al. 2014; McMullen and Warnick 2016). By this view, social enterprises represent an altruistic form of capitalism bounded by the operation of moralised markets (Fourcade and Healy 2007; Tan et al. 2005).

Critics challenge this "grand narrative" of social entrepreneurship and its optimistic vision of social enterprise as a means to achieve harmonious social change and transformation (Dey and Steyaert 2010). One of the grand narrative critiques most relevant to FBOs is that social entrepreneurship can represent "a Trojan horse of capitalist expansion" into the civil sector by introducing a market-oriented approach to solving complex social problems (Dey and Marti 2019, p. 155). If free-market capitalism and its values are regarded as prime causes of social inequality, social exclusion and environmental degradation, then the market mechanisms and values embraced and promoted by the grand narrative cause faith-based practitioners to question whether social entrepreneurship is a suitable tool for addressing these problems (Whittam and Birch 2011).

Social entrepreneurship conducted in a religious, specifically Christian, context may offer a constructive alternative to this grand narrative and its critique (McVea and Naughton 2021). Unrestrained commercial activity in the market-based, capitalist economic system advocated by liberal economic thought has unquestionably produced adverse social and environmental consequences, as faith-based and secular social entrepreneurs would readily acknowledge. However, religious faith and worldview provide a contextual influence that constrains private self-interest in the operation of markets by emphasising other-regarding values of justice and benevolence (Graafland and Wells 2021). In particular, the moral and ethical teachings of the Abrahamic religions (Judaism, Christianity and Islam) on social responsibility provide a context for entrepreneurship that challenges, on the one hand, the view that a free market is the best way to create social benefit and, on the other, the argument that capitalism is inherently and irredeemably evil (Leo XIII 1891). This assertion that religion provides a context that changes the "rules of the game" (Ocasio 1997, p. 196) for social enterprises is developed further in the following sections.

\subsection{An Institutional Logic of Religion}

A 'theological turn' in the broader field of organisation and management scholarship has only recently recognised religion's significance in organisational life (Baker and Dinham 2017; Dyck 2014; Herzog et al. 2020; Smith et al. 2019; Tracey et al. 2014). Scholars now contend that religious faith and values underpin both economic behaviour (McVea and Naughton 2021; Smith et al. 2019, 2021) and social action directed at alleviating poverty and inequality (e.g., Greenwood et al. 2010; Gümüsay 2020; Zhao and Lounsbury 2016). However, few empirical investigations have explored how religion influences the institutional logics that shape organisational behaviour (Fathallah et al. 2020; Greenwood et al. 2010; Gümüsay 2020).

Sociologists propose that human interactions are structured and guided by seven societal-level institutional orders: markets, corporations, professions, states, families, communities and-significantly for this study-religion (Thornton et al. 2012). Institutional 
logics are the "rules of the game" (Ocasio 1997, p. 196) that enact and reinforce these institutional orders. Thornton and Ocasio $(1999$, p. 804) lucidly define institutional logics as "the socially constructed, historical patterns of material practices, assumptions, values, beliefs and rules by which individuals produce and reproduce their material subsistence, organise time and space and provide meaning to their social reality".

In contrast to spirituality, religion provides a collective, fixed and organised expression of cosmology, identity, membership, values, purpose, ideology, transcendence and personal connection (Ashforth and Vaidyanath 2002). Religion has been frequently and variously defined, prompting the often-quoted observation that "It is a truism to say that any definition of religion is likely to be satisfactory only to its author" (Yinger 1967, p. 18). Definitions of religion generally fall into theological, anthropological and contextual-historical categories (Moberg 2002). Representing the anthropological approach, I adopt for this research the following definition of religion:

Religion is a group phenomenon involving group norms that specify beliefs, attitudes, values, and behaviours relating to both sacred and secular aspects of life, which are integrated and imbued with meaning by an ideological framework and worldview. (Hogg et al. 2010, p. 73)

Until recently, religion and its expression in organisational life have received less scholarly attention from organisation and management scholars than the market and community institutional orders (Baker and Dinham 2017; Dyck 2014; Herzog et al. 2020; Tracey et al. 2014). Religion is unique among the societal-level institutional orders since religion influences the market, corporation, professional, state, family and community (or social welfare) orders and the logics that arise from them (Thornton et al. 2012). For this reason, Gümüsay (2020, p. 868) proposes that religion is a "metalogic" that does not merely interact with other logics. The religious logic has a superordinate influence on how organisations interpret and enact these logics due to religion's ubiquity, uniqueness and ultimacy.

While academic literature that explores the relationship between religion and entrepreneurship is abundant (e.g., Dana 2009; Dodd and Seaman 1998; Hoogendoorn et al. 2016), only a handful of studies explore religion's influence on entrepreneurial behaviour from the perspective of 'bottom line' institutional logics. Greenwood et al. (2010) find that religious and family logics promoted by the Catholic Church tempered a commercial logic when Spanish firms dismissed employees. Multiple case study research into Muslim and Christian family firms shows the fluid influence of a religious logic on the other institutional logics that shape ethical decision making (Fathallah et al. 2020). A recent study of an Islamic bank in Germany concludes that commercial and religious logics co-exist in a paradoxical relationship. Researchers conclude that organisations manage the paradox by responding to contrasting logic prescriptions through what they term 'elastic hybridity' (Gümüsay et al. 2020).

\subsection{Institutional Logics of Social Enterprises}

Social enterprises are regarded as organisational hybrids because they incorporate the contrasting, even paradoxical, prescriptions of social welfare and commercial logics (Doherty et al. 2014; Pache and Santos 2013). A social welfare logic arises from the problems, needs and expectations of organisational stakeholders. The commercial logic guides the organisation's trading activity that provides both means and methods to address those problems and needs (Mitzinneck and Besharov 2019; Smith and Besharov 2019). Extensive research and theorising have used the institutional logics perspective to understand how social enterprises incorporate these diverse logics and manage tensions arising from their contrasting prescriptions (Besharov and Smith 2014; Doherty et al. 2014; Pache and Santos 2013; Smith et al. 2013). 


\subsubsection{Logic Tensions in Social Enterprises}

Increasingly, efforts to advance theorising about hybrid organisations such as social enterprises consider the critical influence that values and ethics derived from a particular worldview exert on the logics that shape their goals and activities (Dey and Steyaert 2016; Mitzinneck and Besharov 2019). The context-sensitive perspective this research adopts suggests that organisations experience tension between the logics they embody because these logics express diverse, sometimes conflicting values (Fincham and Forbes 2015; Nielsen and Lockwood 2018). Research and theorising suggest that value multiplicity underlies the tension practitioners and scholars note when describing social enterprises' dual social and entrepreneurial aims (Dees 2012; Zahra et al. 2009).

A significant shortcoming of current scholarship is that it tends to analyse organisational responses to institutional complexity using dichotomous logic pairs (Battilana et al. 2017; Besharov and Smith 2014). Limiting research to logic pairs may be convenient for analytical purposes, but this convenience impedes knowledge and theory building. In contrast to a binary relationship, "when initiatives combine three or more logics, ... the possibility for differences in priority orderings is greater than in dualistic contexts" (Mitzinneck and Besharov 2019, p. 16). Consequently, this research responds to calls to investigate institutional complexity arising from multiple logics (Battilana et al. 2017; Greenwood et al. 2011).

Few studies have investigated social enterprises with three or more logics, a lack that represents a significant knowledge gap. Simplifying analysis to logic pairs may have been necessary to develop initial theories. However, those theories now need to be extended by investigating the more "real world" condition of organisations that incorporate three or more logics and consequently experience more complex inter-logic tensions and framing responses. Research into logic multiplicity in social enterprises has revealed important insights into responses to institutional complexity. Among the extant studies, Mitzinneck and Besharov (2019) identify community, environmental and commercial logics in German renewable energy cooperatives. This study concludes that when organisations incorporate three logics, they manage inter-logic tensions through temporal, structural and collaborative compromises. Pertinent to my research, these cooperatives only experience tension between a commercial logic on the one hand and their community and environmental logics on the other, while they reported no tension between their community and environmental logics. The observation that organisations do not experience all inter-logic tensions equally is especially relevant to my exploration of logic interactions when social enterprises incorporate a third logic of religion.

Empirical research that explores a third institutional logic of religion in social enterprises is scarce. An inductive study of social entrepreneurs in the US by Roundy et al. (2016) finds faith-based social enterprises experience greater institutional complexity due to their religious, social welfare and business logics. Morita (2017) concludes that Evangelical Christian social enterprises in Ethiopia incorporate market, religion, community and family logics and use their religious logic to control the tendency toward mission drift. These studies offer tantalising hints that a religious context and logic influence social enterprises, but to date they are few and inconclusive. The present study aims to address and mitigate this deficiency.

\subsubsection{Responses to Inter-Logic Tensions}

Scholars have identified three generic organisational responses to multiple, contrasting logic prescriptions: differentiating, integrating and accepting paradox (Battilana et al. 2017; Besharov and Smith 2014; Smith et al. 2017). In a differentiating response, organisations manage logic tensions by either eliminating one logic or allowing a single logic to dominate. Conversely, organisations may integrate or hybridise two logics to create a set of consistent, mutually reinforcing and 'aligned' prescriptions. Finally, when logic prescriptions are 'contested' they present the organisation with what appears to be an unresolvable paradox (Besharov and Smith 2014). 
Tensions produced by the contradictory yet inter-related prescriptions of the social welfare and commercial logics inherent in social enterprises can best be described as paradoxical, since "unlike continua, dilemmas, or either/or choices, paradoxical tensions signify two sides of the same coin" (Lewis 2000, p. 761). 'Paradoxical thinking' helps organisations and their members create a superordinate frame of reference that redefines a social paradox, allows seemingly contradictory propositions to co-exist without resolution and enables action by providing a "workable certainty" (Lüscher and Lewis 2008, p. 234; Westenholz 1993). Following Creed et al. (2002, p. 481), I define conceptual frames of reference as "internally coherent interpretative schemas that render events meaningful, organise experience, guide behaviour and motivate action".

A religious worldview can serve as one of those conceptual frames of reference that organisations use to manage tensions between the paradoxical goals they incorporate. Religious faith exerts a multilevel and multidimensional influence on individuals and organisations, even in a secular environment (Cadge and Konieczny 2014; Griebel et al. 2014; Smith et al. 2019). Religious faith and values are elements of a socio-cultural worldview that influences individual, organisational and entrepreneurial behaviour (Hoogendoorn et al. 2016; Kim et al. 2009; Werner 2008). Thus, a religious worldview context brings to the foreground the considerable influence that faith-derived values exert on individual, organisational and societal behaviour (Tracey et al. 2014). Empirical research demonstrates that a person's degree of religiosity (i.e., their normative practise of religion) is positively related to prosocial behaviour (Saroglou 2012), supplying empirical support to the proposition that a religious worldview and values are an unrecognised influence on social enterprises (Spear 2010).

\subsection{Altruistic Love and Giving vs. Self-Interested Exchange}

Scholars have only recently rediscovered love's multilevel influence on individual, organisational and institutional behaviour (Friedland 2013; Tasselli 2019). A Christian religious worldview defines universal, altruistic love as God's other-regarding, self-sacrificial caritas love (Inaba and Lowenthal 2011; Soble 1989). This religious context supplies an explicit motive and rationale for social entrepreneurs to express caritas love individually in Christian faith-based social enterprises (Frémeaux and Michelson 2011; Melé and Naughton 2011). Consequently, a religious worldview expressed through actions that demonstrate altruistic caritas love organisationally and individually can be foundational to the activity of faith-based social enterprises (Benedict XVI 2009; Dees 2012; McCann 2011).

Gift-giving in social and economic transactions is still a puzzle for anthropologists and economists (Dolfsma et al. 2009). One unresolved question is the motivation behind giving a gift: is gift-giving always instrumental and transactional, or can gifts be given without expectation of return? The literature variously defines this second gift type as a gratuitous (de Peyrelongue et al. 2017), perfect (Carrier 1990) or existential gift (Frémeaux and Michelson 2011). A 'pure' gift has two characteristics. First, givers do not use price to measure the gift's worth and second, the gift is unrestrained and unrestraining since reciprocity is neither desired nor expected (Anderson 1990).

If purely self-disinterested, non-reciprocal giving exists, it challenges the dominant capitalistic homo economicus model of instrumental economic exchange based on selfinterest (Belk and Coon 1993; Dolfsma et al. 2009). The possibility that altruistic giving can exist suggests that social enterprises could be motivated by and engage in socially beneficial commercial activity based on non-transactional giving rather than free-market instrumental exchange. Therefore, non-transactional giving motivated by altruistic caritas love as exemplified in faith-based social enterprises can provide a compelling alternative economic model that recognises the role of religion and a religious logic in entrepreneurial behaviour. This observation reinforces the recent statement by entrepreneurship scholars that "it is time to augment the dominant economic paradigm with an alternative and complementary perspective provided by religion" (Smith et al. 2021, p. 2). 
Based on this review of literature, I conclude that faith-based social enterprises foreground the influence of a religious worldview, selfless love and non-transactional giving on the behaviour of social enterprises. This conclusion offers a compelling alternative view of economic behaviour and institutional complexity in social enterprises. From this view, social enterprises are hybrid organisations that respond to tensions between the non-market (social welfare) and market (commercial) goals they incorporate by adopting a superordinate frame of reference. This frame of reference is composed of an overarching religious logic expressed as altruistic caritas love and self-disinterested giving derived from religious faith (Grassl 2011).

\section{Methodology}

This study responds to the question 'How does a religious logic influence the ways social enterprises experience and manage tensions created by their multiple institutional logics?' Consonant with the inquiry's exploratory, theory-building purpose, I adopted a qualitative research paradigm that reflects a constructivist perspective modified by realism. The preponderance of researchers who study social enterprises adopt this approach, as revealed in a systematic literature review conducted by Lehner and Kansikas (2013). I chose a multiple case study design (Stake 2006) for its utility in investigating complex social phenomena and inductively developing generalisable theoretical conclusions (Eisenhardt and Graebner 2007). Organisations are the primary level of analysis and define the 'cases' explored, though the study also considers individual and societal dynamics since social entrepreneurship is a multilevel phenomenon (Saebi et al. 2019).

\subsection{The Case Studies}

My goal was to construct a set of cases reflecting balance, variety, relevance to the study topic and the opportunity to learn (Stake 2006; Yin 2014). As recommended for an instrumental multiple case study design, I selected organisations using non-probability purposeful sampling rather than representative sampling (Eisenhardt and Graebner 2007; Stake 2006; Yin 2014). I created a pool of candidate social entrepreneurial organisations located in the Philippines, Thailand and Vietnam and limited FBOs to those that express the Christian religious faith. These delimitations provided a unique and rich data set from a diverse group of Global South countries (rather than from Europe and North America), controlled the scope of the investigation and took advantage of privileged access and insights I bring to the research task. My prior professional relationships offered unique access to social enterprises in Southeast Asian countries. Consequently, candidates were initially identified from this context. I then expanded the search for potential candidates by conducting internet searches to identify other social enterprises in the target countries and added these organisations to constitute the final pool.

By the end of case selection, the pool comprised eight social enterprises based in the Philippines, Thailand and Vietnam. The final number of cases fits within the range of four to ten considered sufficient to develop valid theoretical generalisations from multiple case study research (Eisenhardt 1989). These countries represent diverse cultural, political and religious environments, thereby improving the generalisability of conclusions. Selected social enterprises were mature, ensuring they had experience in managing their inter-logic tensions. All were micro-enterprises with 3-14 employees and 5-150 direct beneficiaries.

A matched pair comparative case design (Hockerts 2010; Pache and Santos 2013) permitted analysis of between-group and within-group data about how a religious logic, love and gratuitous giving influence the ways these organisations manage paradoxical tensions across different national, cultural and religious contexts (Eisenhardt 1989). Organisations were separated into secular, faith-inspired and faith-based groups and three country-specific groups to facilitate within- and between-group data analysis. Table 1 summarises the cases.

I have chosen to reveal the identities of organisations and individuals that took part in the study and directly attribute data to them in the Findings section. Founder-leaders 
did not request anonymity for themselves or their organisations. Organisations are named and data are directly attributed to study participants to promote research transparency and provide the reader with an opportunity to validate findings and conclusions.

Table 1. Categorisation of Cases.

\begin{tabular}{cccc}
\hline $\begin{array}{c}\text { Country } \\
\text { (Total Number) }\end{array}$ & Faith-Based & Faith-Inspired & Secular \\
\hline Philippines (4) & $\begin{array}{c}\text { Samaritana } \\
\text { Transformation } \\
\text { Ministries }\end{array}$ & $\begin{array}{c}\text { Jacinto and Lirio (J\&L) } \\
\text { Katutubong Kamay } \\
\text { Handicrafts Company } \\
\text { (KKHC) }\end{array}$ & Habi Footwear \\
\hline Thailand (2) & Thai Village & & $\begin{array}{c}\text { Women's Education for } \\
\text { Advancement and } \\
\text { Empowerment (WEAVE) }\end{array}$ \\
\hline Vietnam (2) & Bright Solutions & $\begin{array}{c}\text { Centre for Social } \\
\text { Research and }\end{array}$ \\
& & Development (CSRD) \\
\hline
\end{tabular}

I categorised organisations as secular if their founders did not identify religious faith as an inspiration for their venture. In line with the study's definition of FBOs in the paper's Introduction, I classified organisations as faith-based if founder-leaders identified and expressed religious faith as a central motivation for themselves, the organisation and its programs. By contrast, I concluded that faith-inspired organisations did not incorporate religious practices in their operation even though founders identified religious faith as the personal inspiration for their venture. Structuring case study organisations in this way facilitated data analysis and generation of within-group (literal replication) and betweengroup (theoretical replication) comparative findings, a practice that contributes to the validity and generalisability of the study's conclusions (Yin 2014).

In the Philippines, I studied the secular organisation Habi Footwear, faith-inspired organisations Jacinto and Lirio (J\&L) and Katutubong Kamay Handicrafts Company (KKHC) and faith-based Samaritana Transformation Ministries_-all based in Manila. Habi Footwear, the business name of Sosyal Revolution, Inc., is a small for-profit, privately held corporation. Habi manufactures and sells footwear made from recycled tyres, jute fibre and 'upcycled' t-shirt remnants woven into mats by women in low-income neighbourhoods. J\&L produces and markets ethically and sustainably produced bags, wallets, journals and planners made by partner groups in low-income communities from 'plant leather' based on the water hyacinth. KKHC advocates for change in the social and economic structures that disadvantage Indigenous peoples through the design, production and sale of fashion jewellery based on traditional materials and handicraft skills of two partner Indigenous people groups. Faith-based social enterprise Samaritana is a non-profit organisation to address problems of prostitution and human trafficking. It bases programmes on a Christian holistic or transformational development model (Myers 1999) that incorporates social, spiritual, intellectual and economic interventions. Samaritana does not require its beneficiaries and partners to adhere to its religious traditions.

I studied the secular organisation Women's Education for Advancement and Empowerment (WEAVE) and faith-based Thai Village, both based in Thailand. Established as a charitable foundation in Chiang Mai in 1990, WEAVE started a subsidiary for-profit social enterprise, Fair Trade Social Enterprise, Ltd., in 2012. Its social enterprise markets traditional handloom products made by Indigenous women in camps for displaced persons and rural Thai villages. Thai Village is a charitable foundation that addresses poverty, loss of cultural identity and social exclusion of women, Indigenous groups and the disabled through handicraft production, community and economic development, vocational training and emotional and spiritual care. Founded in 2004 and related to the US-based Wisconsin Evangelical Lutheran Synod, Thai Village openly identifies itself as a faith-based 
social enterprise. Like Samaritana, adherence to its religious tradition is not a requirement for its beneficiaries and partners.

In Vietnam, I conducted research with the Centre for Social Research and Development (CSRD) and Bright Solutions. CSRD, a secular non-profit community development organisation based in Huế in central Vietnam, opened its social enterprise, 'Susu Xanh Organic Vegetable Store,' in 2016 to support farmers adopt organic agricultural techniques and generate income for CSRD. Change in senior leadership and a funding crisis caused CSRD to sell Susu Xanh to one of the shop's managers in 2018. Bright Solutions Co. Ltd. is a for-profit company founded in 2009 in a low-income district of Ho Chi Minh City to provide vocational training and income to women by manufacturing and selling handcrafted early education products for children. I classified Bright Solutions as a faith-based social enterprise even though Vietnamese law and its internal policies prohibit it from openly identifying religious faith as a motivation for its programs. This classification is appropriate since the company is owned by Global Mission Partners, the cross-cultural mission agency of the Churches of Christ in Australia. Bright Solutions halted operations and was closed in 2020 due to the impact of the COVID-19 pandemic on its supply chains and markets.

\subsection{Data Collection and Analysis}

Fieldwork and data analysis progressed concurrently in three phases from April 2016 to September 2017, a synergistic approach common in interpretive, qualitative research. Twenty-four interviews were conducted in total by the end of the third fieldwork phase. In the first phase, selection criteria and interview protocols were prepared based on constructs from the inquiry's theoretical lenses and informed by relevant literature. Extensive desk research conducted during this phase provided archival data on organisations and their settings that informed in-person interviews.

In the second phase, I visited each organisation and conducted semi-structured interviews lasting from one to two hours using a standard protocol to ensure data reliability and consistency (Eisenhardt 1989). The interview protocol included questions about the organisation, its history, accomplishments and challenges. Eleven interviews were conducted during this phase. The third phase involved follow-up visits and in-person interviews at four organisations (Habi, Samaritana, Thai Village and WEAVE) to clarify and expand on emergent themes and collect new archival material, reflecting the iterative nature of qualitative research and data analysis. I could not return to Vietnam to revisit Bright Solutions and CSRD in person and conducted follow-up interviews with these organisations through email and Skype. Thirteen more interviews conducted in the third phase allowed me to explore emergent themes in greater depth and gain a broader, longitudinal perspective.

Figure 1 depicts the data collection and analysis steps used to generate findings.

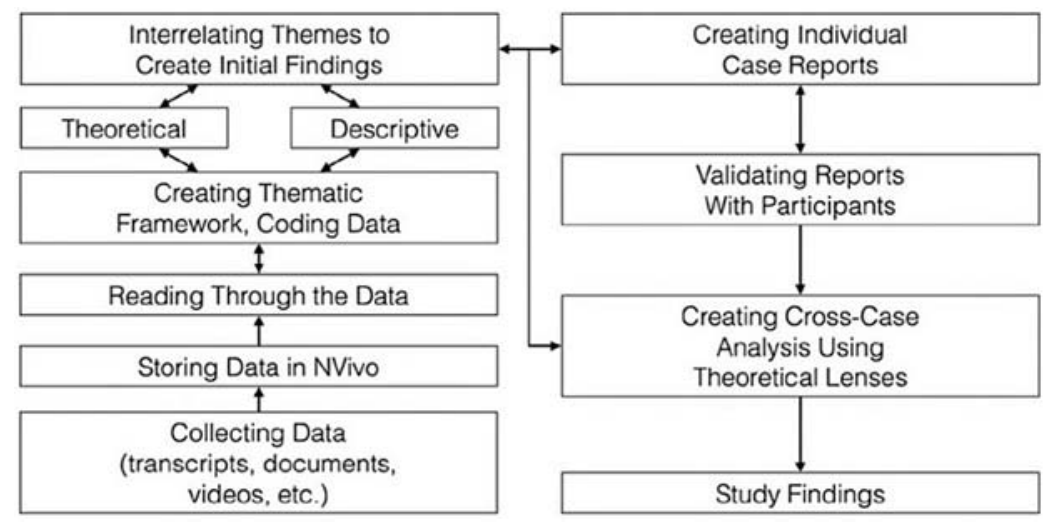

Figure 1. Data Collection and Analysis Steps.

Data analysis proceeded in three steps. First, data collected through semi-structured interviews, observation and documentary evidence were stored and analysed using the 
qualitative data analysis software NVivo 11. Research data comprised recorded interviews and transcriptions, 160 videos and more than 458 archival documents, including datasets drawn from the organisations' websites, social media accounts and news reports. I reviewed interview and archival data multiple times to get a sense of the material, which enabled me to find emergent themes and revise the interview guide accordingly during fieldwork. Simultaneous analysis of interview transcripts, archival material and field observations supplied a rich dataset for each organisation (Stake 2006; Yin 2014), a check on retrospective rationalisation by interviewees (Eisenhardt 1989) and greater construct validity.

Second, data were analysed thematically through deductive and inductive coding in a multi-step iterative process (Spencer et al. 2014). Initial coding was deductive based on "potentially important constructs" (Eisenhardt 1989, p. 536) drawn from the investigation's theoretical lenses to provide an empirical foundation for developing theory. The second round of coding introduced inductive, emergent codes that identified descriptive multilevel organisational characteristics to supplement the a priori theoretical codes. Table 2 presents the thematic framework and codes developed during data analysis.

Table 2. Thematic Framework.

\begin{tabular}{|c|c|}
\hline $\begin{array}{c}\text { Theoretical Codes } \\
\text { (Deductive and Inductive) }\end{array}$ & Descriptive Codes (Inductive) \\
\hline 1. Logics & 1. Context \\
\hline 1.1. Commercial (deductive) & 1.1. What: Problem definition \\
\hline 1.2. Social welfare (deductive) & 1.2. Where: Geography \\
\hline 1.3. Religious (deductive) & 1.3. How: Socio-economic factors \\
\hline 1.4. Tension social-commercial (inductive) & 1.4. Who: Beneficiaries and leaders \\
\hline 1.5. Tension commercial-religious (inductive) & 1.5. When: History \\
\hline 1.6. Tension social-religious (inductive) & 1.6. Why: Rationale \\
\hline 2. Values & 2. Framing \\
\hline 2.1. Self-transcending (deductive) & 2.1. Altruistic love \\
\hline 2.2. Religious worldview (inductive) & 2.2. Non-transactional giving \\
\hline
\end{tabular}

During the third analysis step, I prepared individual case reports following Stake (2006) and Yin (2014). Draft case reports were presented to the participating organisations to validate data and conclusions and to solicit and incorporate corrections and comments. Cross-case analyses of the corrected reports produced a matrix of findings and themes on how organisations experience and manage inter-logic tensions (Stake 2006). Findings emerged inductively using the theoretical lenses to interrogate the data and identify patterns that responded to the research questions.

\section{Findings}

This study aimed to investigate how faith-based, faith-inspired and secular social enterprises experience and manage tensions between the institutional logics that determine their goals and operation (Fincham and Forbes 2015). I was specifically interested in how religious logic prescriptions interact with the organisations' social welfare and commercial logics (Morita 2017; Roundy et al. 2016). The following analysis shows how distinctions between the three organisational types served as a basis for theorising from the study's findings.

\subsection{Inter-Logic Tensions}

Analysis of findings examined tensions between social, commercial and religious logics and organisational responses to these tensions following the iterative pair-wise analysis recommended by Besharov and Smith (2014). Table 3 presents my analysis of the data.

I proceed to explore inter-logic tensions and organisational responses in the four logic combinations shown in Table 3. 
Table 3. Experience and Management of Logic Tensions.

\begin{tabular}{|c|c|c|c|}
\hline Logic Tension & Secular & Faith-Inspired & Faith-Based \\
\hline Social welfare + commercial & \multicolumn{3}{|c|}{ These conflicting prescriptions are paradoxical, presenting a constant and unavoidable challenge } \\
\hline Commercial + religious & None & \multirow{2}{*}{\multicolumn{2}{|c|}{$\begin{array}{l}\text { Tensions are less acute than between social welfare and commercial logics } \\
\text { No tension. Prescriptions are equally valid, compatible and } \\
\text { interdependent }\end{array}$}} \\
\hline Social welfare + religious & None & & \\
\hline $\begin{array}{l}\text { Social welfare }+ \text { commercial }+ \\
\text { religious }\end{array}$ & None & $\begin{array}{l}\text { A religious logic is the context of } \\
\text { other logics }\end{array}$ & $\begin{array}{l}\text { A religious metalogic frames the } \\
\text { other logics }\end{array}$ \\
\hline Altruistic love and giving & \multicolumn{3}{|c|}{$\begin{array}{l}\text { SE is understood as altruistic, non-transactional giving that empowers beneficiaries } \\
\text { Love is defined personally as sentiment and friendship }\end{array}$} \\
\hline
\end{tabular}

\subsubsection{Social Welfare + Commercial Logic Tensions}

Founder-leaders describe the tension produced by conflicting demands of social welfare and commercial logics as a constant and unavoidable challenge in their organisations, a situation described by Mitos at WEAVE as "caught in the middle". Similarly, Jonathan Nambu of Samaritana aptly refers to the tension a commercial logic produces in a non-profit organisation as "the elephant in the room":

There's always been an elephant in the room that no one has either acknowledged or known how to talk about in terms of the tension between how we have identified and defined ourselves as a non-profit group and the whole idea of earning money.

The principal approach organisations adopt to manage the institutional complexity introduced by their social welfare and commercial logics is to frame their prescriptions as "conflicting-yet-complementary" demands that exist in a paradoxical relationship (Smets et al. 2015, p. 962; Smith et al. 2017). Founder-leaders report that the two logics generate persistent and unresolvable paradoxical tensions that simply must be lived with, appreciated and embraced. Conflicts inherent in organisations that operate as work integration social enterprises (WISEs) supply a compelling example (Pache and Santos 2013). Apart from CSRD, the organisations studied can be classified as WISEs that supply employment and training to persons disadvantaged by poverty, trauma, systemic discrimination, or disability. Because of their circumstances, beneficiaries can be problematic, less productive workers who require a more significant investment of time and resources. Katie describes how Thai Village experiences the paradoxical inter-logic tension inherent in a WISE:

The people coming to us are people in need. The more in need they are, the harder they are to help. The more help they need, the harder it is to do that. The more that we want to help, the harder it is to do.

\subsubsection{Commercial + Religious Logic Tensions}

Faith-based and faith-inspired social enterprises incorporate and manage tensions between the prescriptions of their commercial and religious logics. These organisations say they experience tension produced by the two logics' conflicting demands but describe the tension as less acute than between social welfare and commercial logics. Founder-leaders at faith-inspired social enterprises J\&L and KKHC describe the tension as a struggle to maintain their Christian religious faith and values in business management decisions. Churchille experiences the tension between her religious faith and the stylised Indigenous anting-anting amulets KKHC sells as a paradox she must live with: "The religious tension is one of my biggest challenges and struggles".

Faith-based social enterprises reframe and respond to these same inter-logic tensions by prioritising ethical business practices consistent with their Christian religious faith and values. Samaritana incorporates normative moral and religious values of justice and fairness in its enterprise's policies and procedures and prioritises a religious over a commercial logic, as described by Thelma: "In that sense, we put our Christian values ahead of the business". Full-time staff at Thai Village attend a weekly half-day meeting 
on Friday that includes Bible study and prayer, which production manager Katie Lehman views as an expression of how the organisation prioritises logics:

It's not productive to stop and pray for half a day in a business ... We feel like we're always busy, and there are always things to do, but we're still doing it. We prioritise the spiritual over the business in the same way we prioritise the social over the business.

\subsubsection{Social Welfare + Religious Logic Tensions}

Faith-based and faith-inspired social enterprises describe the distinctive prescriptions of their social welfare and religious logics as equally valid, compatible and interdependent. They do not experience tension between these two logics, but frame their prescriptions as integrated, consistent and mutually reinforcing. Anne at faith-inspired organisation J\&L exemplifies the integration of social welfare and religious logics in the statement: "The spiritual and social values do work together. After all, we are asked to help the poor".

Faith-based social enterprises Samaritana and Thai Village integrate social welfare and religious logics in their programs more intentionally and explicitly than faith-inspired organisations. Social welfare and religious logic prescriptions are aligned and integrated theologically in Katie's observation that at Thai Village the two logics "might be the most compatible to me. These are things Jesus teaches, and the reason why we want to be doing the social things is because of our faith". Bright Solutions operates in a context in which it must exercise care to express a religious logic. However, Fiona links the organisation's programs with her religious faith and worldview in the statement: "It's about development processes, but because of who we are and our faith, that's why we do what we do".

\subsubsection{Social Welfare + Commercial + Religious Logic Tensions}

As expected, Table 3 shows faith-based and faith-inspired social enterprises experience greater institutional complexity due to the social welfare, commercial and religious logics they incorporate. Consequently, their organisational tensions and responses are more complex. Founder-leaders at the faith-inspired organisations refer to the biblical and theological mandates that frame and integrate their social welfare and commercial logics when they describe their activities. Noreen draws upon a papal encyclical to explain how she views the work of J\&L: "I remember that around 2010 I was deeply influenced by Pope Benedict XVI's Encyclical, 'Caritas in Veritate' (Benedict XVI 2009). There are a number of lines in the encyclical that make a case for social entrepreneurship".

By contrast, faith-based social enterprises incorporate the three logics more explicitly than do faith-inspired organisations. Katie's statement about decision making at Thai Village illustrates the dynamic, even paradoxical relationship between these three logics: "The reason why we sometimes don't make good business choices is because our faith is telling us that the social is important". I interpret Katie's observation to mean that Thai Village uses a religious logic characterised by altruistic love and gratuitous giving to frame and manage tensions between the conflicting social welfare and commercial logic prescriptions it incorporates, thereby mitigating mission drift.

\subsection{Inter-Logic Tensions Framed by Altruistic Love and Giving}

Study data show that altruistic love and non-transactional giving motivated by empathy and expressed as compassion and care supply a frame of reference that helps social enterprises manage paradoxical inter-logic tensions (Lambrechts et al. 2020). This frame has its origin in other-regarding, self-transcending values based on a religious worldview, reflecting the prosocial, compassionate action to benefit the less fortunate that is a distinct feature of social enterprises (Miller et al. 2012) and religious faith and values (Goetz et al. 2010).

Social enterprises express altruistic love through programs that show care, compassion and non-transactional giving, but in diverse ways depending on their religious faith 
orientation. Secular and faith-inspired organisations refer to love in the sentimental and friendship senses. In contrast, faith-based organisations describe love in the altruistic, universal caritas sense of compassionate action and care (Inaba and Lowenthal 2011; Soble 1989). This statement by Bright Solutions about its work with disadvantaged women exemplifies altruistic caritas love:

Bright Solutions' desire is to love and accept each broken life. As we seek to love each, reclaiming value and purpose, these women start to laugh; they look forward to work in a community of peace and safety where their futures do not need to be as dark as once thought. [Facebook page]

Altruistic love expressed as compassion reveals the practice of 'pure' gift-giving over a utilitarian exchange in these organisations (Grassl 2011; McCann 2011). Secular, faith-inspired and faith-based social enterprises describe their activity as altruistic, non-transactional giving that seeks to help and empower beneficiaries. They provide disadvantaged women with opportunities they might not otherwise receive from the state or a competitive commercial market. Janine succinctly describes Habi's relationship with the women who produce the raw materials for its shoes not as a commercial transaction but as "giving them opportunities they haven't witnessed yet". They sacrifice efficiency and potential profits to supply income and employment to those who have suffered trauma, multiple disadvantages and social exclusion. They accept smaller profit margins on their products to maximise beneficiary incomes and hold prices down to promote social change goals by making their products more affordable. Founder-leaders say they accept lower, or no, salaries and more challenging working conditions than they would receive from alternative employment in a competitive labour market. However, rather than characterising this situation as a personal sacrifice, founder-leaders describe their work as a gift that fulfils their life's purpose. Noreen, a founder at J\&L, described her social enterprise as "a vehicle to channel our God-given talents and work on our passion to make a difference in society".

Faith-based social enterprises frame altruistic love and gift-giving more explicitly in theological and transcendent terms. This framing supplies the clearest example of a nontransactional relationship between social enterprises and their stakeholders. Their founderleaders identify God as the ultimate gift-giver and themselves and their organisations as recipients and channels of those gifts, characterising their activity as gift-giving enacted in response to God's generosity. Further, they describe their programs as a means to share and thereby multiply God's gifts for social benefit. Samaritana presents altruistic giving and compassion shaped by a religious worldview and values as the frame for its programs. Its website states: "We believe that as recipients of the compassionate love of God as individuals and as a community, we must extend compassion particularly towards the marginalised and vulnerable among us such as these women". Katie, a leader at Thai Village, describes her organisation's goal to provide economic security to disadvantaged populations in northern Thailand as a response to the biblical commandment to show caritas love to God and others:

Jesus said, "Love the Lord your God with all your heart and all your soul and all your mind and love your neighbour as yourself". We are doing both of those things. Not just one, and not just the other, but both. It's both/and.

In conclusion, secular, faith-inspired and faith-based social enterprises manage institutional complexity arising from the multiple logics they incorporate by framing interlogic tensions in terms of altruistic, caritas love and non-transactional giving. Further, other-regarding values based on a religious logic underpin this prosocial framing of the paradoxical tensions between social welfare and commercial logics. Churchille manages the tension between religious and commercial logics by framing them in terms of KKHC's social mission, reasoning that the spiritual power of the charms she sells comes from helping partner Indigenous communities: “I don't believe these raw materials have power. 
I say the charm that benefits the wearer is the goodwill created by buying these products that puts meals on their tables and gives an allowance to their kids".

Noreen aptly describes this framing process through the story of a large commercial order that was delayed because of production problems in J\&L's partner community. She and co-founder Anne experienced a great deal of stress trying to satisfy the customer and work with their community producers. In other words, J\&L's commercial and social welfare logic prescriptions were in direct conflict and trapped its founder-leaders in a paradox. Noreen said when the order was finally delivered and payment was made to the producers:

One of the mothers texted me and said, 'Miss Noreen, thank you so much for this order. I know it's been stressful, but this will be a big help since our neighbour just had a caesarean operation and needed me to help pay for it.' The other one said her husband had a goitre and needed it treated. And I cried: it was all worth it".

Noreen's tears and her conclusion "it was all worth it" suggest that in this situation, altruistic love and giving supplied a frame of reference that put the demands of the organisation's commercial and social welfare logics in perspective. This narrated experience illustrates how inter-logic tensions are framed and managed at J\&L through a story that endures today.

\section{Discussion and Conclusions}

This research addresses notable research gaps in how hybrid organisations like social enterprises experience and respond to multiple institutional logic prescriptions. Specifically, the study was conducted to identify how a religious logic influences the ways these organisations manage institutional complexity. Toward this end, I develop an empirically derived model that extends current theorising about how social enterprises manage multiple, often competing institutional logic prescriptions.

The model presented in Figure 2 encapsulates findings from a matched-pair multiple case study of secular, faith-inspired and faith-based social enterprises. My investigation suggests that social enterprises respond to institutional complexity by adopting a superordinate frame of reference that helps them manage the inherently paradoxical prescriptions of the social welfare and commercial logics they incorporate. This frame of reference is composed of self-transcending values, a religious metalogic, altruistic caritas love and non-transactional giving.

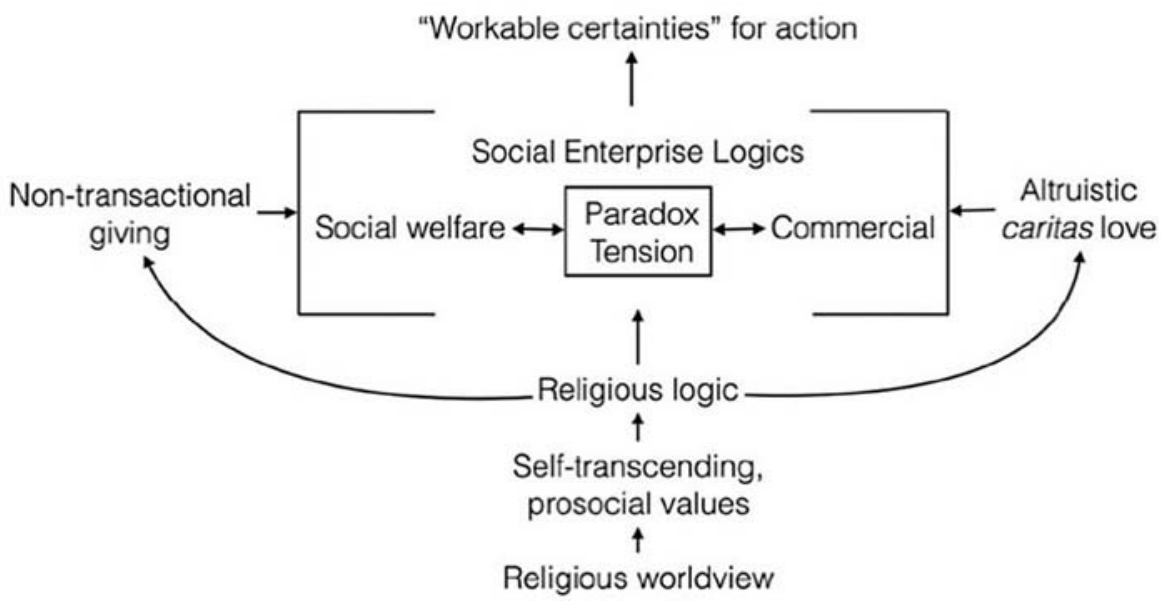

Figure 2. Contextual model.

The model suggests that social enterprises manage tensions between the paradoxical social welfare and commercial logics they incorporate by referencing a commonly held worldview. Secular enterprises cope with their paradoxical logic prescriptions by 
referencing a worldview based on shared prosocial values. In contrast, faith-based and faith-inspired enterprises frame logic prescriptions in terms of their religious worldview and values (Griebel et al. 2014). This contextual framing allows multiple logic prescriptions to co-exist in a "conflicting yet complementary" relationship (Smets et al. 2015, p. 962; Smith et al. 2017). Secular social enterprises express a religious logic implicitly, while faith-inspired and faith-based social enterprises express the logic explicitly (McVea and Naughton 2021; Smith et al. 2019).

This study offers evidence that faith-inspired and faith-based social enterprises experience and manage greater institutional complexity than their secular counterparts, since in a religious faith context these organisations express three institutional logics. In contrast, social enterprises only express two logics in a secular context.

Further, religion exerts a superordinate influence that defines and moulds how organisations express other institutional logics (Gümüsay 2020; Gümüsay et al. 2020). Thus, a religious context and metalogic explicitly shape the activity of faith-based social enterprises. A religious metalogic provides these organisations with a frame of reference to navigate the complex prescriptions of their paradoxical social welfare and commercial logics. Therefore, I conclude that faith-based and faith-inspired social enterprises manage tensions created by the paradoxical logic prescriptions of their social welfare and commercial logics by framing and redefining them in terms of a religious metalogic (Mongelli et al. 2019; Morita 2017; Roundy et al. 2016).

Finally, the model asserts that social enterprises manage tension between their multiple, inherently conflicting goals by framing logics in terms of non-transactional giving and altruistic caritas love. This conclusion offers a compelling alternative view of how social enterprises manage institutional complexity by examining them through a lens of non-transactional giving motivated by religion-inspired altruistic love that is expressed organisationally and individually (McCann 2011). I extend scholarship by suggesting in the model that a religious worldview underpins the foundation of other-regarding values in social enterprises, whether explicitly in faith-based and faith-inspired initiatives or implicitly in secular organisations (Cadge and Konieczny 2014; Goetz et al. 2010; Kim et al. 2009; Spear 2010).

The model suggests that social welfare and commercial logics present a paradox only when framed by a utilitarian, instrumental view of human relationships and economic transactions (Anderson 1990; Belk and Coon 1993; Dolfsma et al. 2009; McVea and Naughton 2021). This study reveals that social enterprises transcend logic paradoxes by framing their logics with altruistic caritas love and giving (Grassl 2011; Gümüsay 2020; Smith et al. 2013). Thus, study conclusions extend extant scholarship on caritas love and the gratuitous, "existential gift" in the business ethics of commercial entrepreneurship and apply this knowledge to social enterprises (Frémeaux and Michelson 2011, p. 63; Melé and Naughton 2011; McCann 2011; Werner 2008).

I note the usual limitations and advantages of the qualitative, interpretivist approach adopted for this investigation. Generalisability to contexts other than those in which the research was conducted is limited, albeit compensated for by greater depth and descriptive richness. Additionally, a constructivist research perspective recognises the researcher's role and positionality as both a strength that aids data interpretation and as a weakness that potentially limits and colours interpretation (Creswell 2014). In response to these concerns, the case study design and sampling method I used provide literal and theoretical replication, enhancing the ability to draw theoretical generalisations from data rather than rationalistic, propositional and law-like generalisations (Creswell 2014; Yin 2014).

This study and the model derived from its empirical data provide a foundation for future exploratory research into the influence of religious faiths other than Christianity on institutional complexity in social enterprises. It signals opportunities to explore social enterprises in the rarely investigated context of other world religions such as Islam, Buddhism, Hinduism and Judaism. For instance, the rapidly developing literature on Islamic social enterprises contends that an Islamic worldview differs from a secular worldview in 
how it defines reality (ontology), knowledge (epistemology) and values (axiology) (Aydin 2015). Recent scholarship on Islamic social and commercial enterprises underscores the moderating influence of a religious metalogic grounded in faith-based prosocial moral and ethical values on economic transactions (Alarifi and Alrubaishi 2018; Gümüsay 2020).

The current investigation recognises but does not explore other dynamics crucial to understanding the influence of intersecting contexts of religious faith, values, situational factors and institutional logics on social enterprises. For example, a Global South context and differences between the national, regional and cultural contexts unquestionably influence the social enterprises I studied (Herzog et al. 2020). The influence of a 'where' context on inter-logic tensions in social enterprises and its intersection with the contexts I studied is a fruitful topic for future research that would test and extend the proposed model (de Bruin and Teasdale 2019).

Finally, I call for further research to examine how religion functions as a 'metalogic' and cognitive frame that helps social enterprises manage tensions between their social welfare and commercial logics. Such research would extend institutional theory and bridge the fields of institutional logics and paradox theory (Gümüsay 2020; Lüscher and Lewis 2008; Westenholz 1993). Additionally, I join the call for research that explores the embeddedness of institutional logics and entrepreneurial behaviour in a context of religioninspired worldview and values (Lee and Lounsbury 2015; Seo and Creed 2002; Smith et al. 2019, 2021; Spedale and Watson 2014).

To conclude, I respond to the question posed in the title, 'what's love got to do with it?' Faith-based social enterprises bring to the foreground a religious worldview expressed as selfless love and non-transactional giving. They reveal that social enterprises use a religious worldview context to manage paradoxical tensions between the prescriptions of their social welfare and commercial goals. Further, faith-based social enterprises highlight the influence of religion on entrepreneurial activity and provide a compelling alternative to the dominant self-interested, capitalistic economic paradigm. I hope that new insights gained from this rich set of empirical data will inspire future research that sheds light on the vital question of how social enterprises use a religious worldview and values to manage inherent inter-logic tensions and paradoxes as they seek to meet human needs and contribute to positive social change.

Funding: This research received no external funding.

Institutional Review Board Statement: The study was conducted according to the guidelines of the Declaration of Helsinki and approved by the Human Ethics Committee of Massey University (Ethics Notification 4000015784, 24 March 2016).

Informed Consent Statement: Informed consent was obtained from all subjects involved in the study.

Data Availability Statement: Qualitative data and analysis documents are available from the author.

Conflicts of Interest: The author declares no conflict of interest.

\section{References}

Alarifi, Ghadah, and Dalal Alrubaishi. 2018. The social enterprise landscape in Saudi Arabia. Academy of Entrepreneurship Journal 24: $1-8$.

Alderson, Keanon J. 2011. At the crossroads: Social and faith-based entrepreneurship. Thunderbird International Business Review 54: 111-16. [CrossRef]

Anderson, Elizabeth S. 1990. The ethical limitations of the market. Economics and Philosophy 6: 179-205. [CrossRef]

Ashforth, Blake E., and Deepa Vaidyanath. 2002. Work organizations as secular religions. Journal of Management Inquiry 11: 359-70. [CrossRef]

Aydin, Necati. 2015. Islamic social business for sustainable development and subjective wellbeing. International Journal of Islamic and Middle Eastern Finance and Management 8: 491-507. [CrossRef]

Baglioni, Simone. 2017. A remedy for all sins? Introducing a special issue on social enterprises and welfare regimes in Europe. Voluntas 28: 2325-38. [CrossRef]

Baker, Christopher, and Adam Dinham. 2017. New interdisciplinary spaces of religions and beliefs in contemporary thought and practice: An analysis. Religions 8: 16. [CrossRef] 
Battilana, Julie, Marya Besharov, and Bjoern Mitzinneck. 2017. On hybrids and hybrid organizing: A review and roadmap for future research. In The SAGE Handbook of Organizational Institutionalism, 2nd ed. Edited by Royston Greenwood, Christine Oliver, Thomas B. Lawrence and Renate E. Meyer. Thousand Oaks: SAGE, pp. 128-62.

Belk, Russell W., and Gregory S. Coon. 1993. Gift giving as agapic love: An alternative to the exchange paradigm based on dating experiences. Journal of Consumer Research 20: 393-417. [CrossRef]

Benedict XVI. 2009. Encyclical Letter: 'Caritas in Veritate' (Charity in Truth). Available online: http://w2.vatican.va/content/benedictxvi/en/encyclicals/documents/hf_ben-xvi_enc_20090629_caritas-in-veritate.html (accessed on 9 December 2019).

Berger, Julia. 2003. Religious nongovernmental organizations: An exploratory analysis. Voluntas 14: 15-39. [CrossRef]

Besharov, Marya L., and Wendy K. Smith. 2014. Multiple institutional logics in organizations: Explaining their varied nature and implications. Academy of Management Review 39: 364-81. [CrossRef]

Borquist, Bruce R. 2020. The Context and Enactment of Faith-Based Social Entrepreneurship. Ph.D. thesis, Massey University, Auckland, NZ, USA.

Bowes, John C. 1998. St. Vincent de Paul and business ethics. Journal of Business Ethics 17: 1663-67. [CrossRef]

Bull, Mike, and Rory Ridley-Duff. 2019. Towards an appreciation of ethics in social enterprise business models. Journal of Business Ethics 159: 619-34. [CrossRef]

Cadge, Wendy, and Mary E Konieczny. 2014. 'hidden in plain sight': The significance of religion and spirituality in secular organizations. Sociology of Religion: A Quarterly Review 75: 551-63. [CrossRef]

Carrier, James. 1990. Gifts in a world of commodities: The ideology of the perfect gift in American society. Social Analysis: The International Journal of Social and Cultural Practice 29: 19-37.

Cnaan, Ram. 1999. Our hidden safety net: Social and community work by urban American religious congregations. The Brookings Review 17: 50-53. [CrossRef]

Creed, W. E. Douglas, Jeffrey A. Langstraat, and Maureen A. Scully. 2002. A picture of the frame: Frame analysis as technique and as politics. Organizational Research Methods 5: 34-55. [CrossRef]

Creswell, John W. 2014. Research Design: Qualitative, Quantitative, and Mixed Methods Approaches, 4th ed. Thousand Oaks: SAGE.

Crisp, Beth R. 2014. Social Work and Faith-Based Organizations. Abingdon: Routledge.

Dana, Léo-Paul. 2009. Religion as an explanatory variable for entrepreneurship. International Journal of Entrepreneurship and Innovation 10: 87-99. [CrossRef]

de Bruin, Anne, and Simon Teasdale. 2019. Exploring the terrain of social entrepreneurship: New directions, paths less travelled. In $A$ Research Agenda for Social Entrepreneurship. Edited by Anne de Bruin and Simon Teasdale. Cheltenham: Elgar, pp. 1-12. [CrossRef]

de Bruin, Anne, Eleanor Shaw, and Dominic M. Chalmers. 2014. Social entrepreneurship: Looking back, moving ahead. In Handbook of Research on Small Business and Entrepreneurship. Edited by E. Chell and M. Karatas-Özkan. Cheltenham: Elgar, pp. $392-416$.

de Peyrelongue, Bénédicte, Olivier Masclef, and Valérie Guillard. 2017. The need to give gratuitously: A relevant concept anchored in Catholic Social Teaching to envision the consumer behavior. Journal of Business Ethics 145: 739-55. [CrossRef]

Dees, J. Gregory. 2012. A tale of two cultures: Charity, problem solving, and the future of social entrepreneurship. Journal of Business Ethics 111: 321-34. [CrossRef]

Dey, Pascal, and Chris Steyaert. 2010. The politics of narrating social entrepreneurship. Journal of Enterprising Communities 4: 85-108. [CrossRef]

Dey, Pascal, and Chris Steyaert. 2016. Rethinking the space of ethics in social entrepreneurship: Power, subjectivity, and practices of freedom. Journal of Business Ethics 133: 627-41. [CrossRef]

Dey, Pascal, and Laurent Marti. 2019. Social entrepreneurship through the lens of the 'everyday': Inquiring the rhythms of female micro-credit recipients. In A Research Agenda for Social Entrepreneurship. Edited by Anne de Bruin and Simon Teasdale. Cheltenham: Elgar, pp. 155-63. [CrossRef]

Dodd, Sarah Drakopolou, and Paul Timothy Seaman. 1998. Religion and enterprise: An introductory exploration. Entrepreneurship Theory and Practice 23: 71-86. [CrossRef]

Doherty, Bob, Helen Haugh, and Fergus Lyon. 2014. Social enterprises as hybrid organizations: A review and research agenda. International Journal of Management Reviews 16: 417-36. [CrossRef]

Dolfsma, Wilfred, Rene van der Eijk, and Albert Jolink. 2009. On a source of social capital: Gift exchange. Journal of Business Ethics 89: 315-29. [CrossRef]

Dorado, Silvia, and Marc J. Ventresca. 2013. Crescive entrepreneurship in complex social problems: Institutional conditions for entrepreneurial engagement. Journal of Business Venturing 28: 69-82. [CrossRef]

Dyck, Bruno. 2014. God on management: The world's largest religions, the "theological turn," and organization and management theory and practice. In Religion and Organization Theory. Edited by Paul Tracey, Nelson Phillips and Michael Lounsbury. Bingley: Emerald, vol. 41, pp. 23-62. [CrossRef]

Eisenhardt, Kathleen M., and Melissa E. Graebner. 2007. Theory building from cases: Opportunities and challenges. Academy of Management Journal 50: 25-32. [CrossRef]

Eisenhardt, Kathleen M. 1989. Building theories from case study research. Academy of Management Review 14: 532-50. [CrossRef]

Fathallah, Ramzi, Yusuf Sidani, and Sandra Khalil. 2020. How religion shapes family business ethical behaviors: An institutional logics perspective. Journal of Business Ethics 163: 647-59. [CrossRef] 
Fincham, Robin, and Tom Forbes. 2015. Three's a crowd: The role of inter-logic relationships in highly complex institutional fields. British Journal of Management 26: 657-70. [CrossRef]

Fourcade, Marion, and Kieran Healy. 2007. Moral views of market society. Annual Review of Sociology 33: 285-311. [CrossRef]

Frémeaux, Sandrine, and Grant Michelson. 2011. 'No strings attached': Welcoming the existential gift in business. Journal of Business Ethics 99: 63-75. [CrossRef]

Friedland, Roger. 2013. God, love and other good reasons for practice: Thinking through institutional logics. In Institutional Logics in Action: Part A. Edited by Michael Lounsbury and Eva Boxenbaum. Bingley: Emerald, vol. 39, pp. 25-50. [CrossRef]

Göçmen, Ipek. 2013. The role of faith-based organizations in social welfare systems: A comparison of France, Germany, Sweden, and the United Kingdom. Nonprofit and Voluntary Sector Quarterly 42: 495-516. [CrossRef]

Goetz, Jennifer L., Dacher Keltner, and Emiliana Simon-Thomas. 2010. Compassion: An evolutionary analysis and empirical review. Psychological Bulletin 136: 351-74. [CrossRef] [PubMed]

Graafland, Johan, and Thomas R. Wells. 2021. In Adam Smith's own words: The role of virtues in the relationship between free market economies and societal flourishing, a semantic network data-mining approach. Journal of Business Ethics 172: 31-42. [CrossRef]

Grassl, Wolfgang. 2011. Hybrid forms of business: The logic of gift in the commercial world. Journal of Business Ethics 100: 109-23. [CrossRef]

Greenwood, Royston, Amalia Magán Díaz, Stan Xiao Li, and José Céspedes Lorente. 2010. The multiplicity of institutional logics and the heterogeneity of organizational responses. Organization Science 21: 521-39. [CrossRef]

Greenwood, Royston, Mia Raynard, Farah Kodeih, Evelyn R. Micelotta, and Michael Lounsbury. 2011. Institutional complexity and organizational responses. Academy of Management Annals 5: 317-71. [CrossRef]

Griebel, Jenna, Jerry Park, and Mitchell Neubert. 2014. Faith and work: An exploratory study of religious entrepreneurs. Religions 5: 780-800. [CrossRef]

Gümüsay, Ali A. 2020. The potential for plurality and prevalence of the religious institutional logic. Business E Society 59: 855-80. [CrossRef]

Gümüsay, Ali Aslan, Michael Smets, and Tim Morris. 2020. 'God at work': Engaging central and incompatible institutional logics through elastic hybridity. Academy of Management Journal 63: 124-54. [CrossRef]

Herzog, Patricia Snell, David P. King, Rafia A. Khader, Amy Strohmeier, and Andrew L. Williams. 2020. Studying religiosity and spirituality: A review of macro, micro, and meso-level approaches. Religions 11: 437. [CrossRef]

Hockerts, Kai. 2010. Social entrepreneurship between market and mission. International Review of Entrepreneurship 8: 177-98.

Hogg, Michael A., Janice R. Adelman, and Robert D. Blagg. 2010. Religion in the face of uncertainty: An uncertainty-identity theory account of religiousness. Personality and Social Psychology Review 14: 72-83. [CrossRef]

Hoogendoorn, Brigitte, Cornelius A. Rietveld, and André van Stel. 2016. Belonging, believing, bonding, and behaving: The relationship between religion and business ownership at the country level. Journal of Evolutionary Economics 26: 519-50. [CrossRef]

Inaba, Keishin, and Kate Lowenthal. 2011. Religion and altruism. In The Oxford Handbook of the Sociology of Religion. Edited by Peter B. Clarke. Oxford: Oxford University Press, pp. 876-89. [CrossRef]

Kim, David, Dan Fisher, and David McCalman. 2009. Modernism, Christianity, and business ethics: A worldview perspective. Journal of Business Ethics 90: 115-21. [CrossRef]

King, Stephen M. 2007. Religion, spirituality, and the workplace: Challenges for public administration. Public Administration Review 67: 103-14. [CrossRef]

Lambrechts, W., M. C. J. Caniëls, I. Molderez, R. Venn, and R. Oorbeek. 2020. Unraveling the role of empathy and critical life events as triggers for social entrepreneurship. Frontiers in Psychology 11: 1-14. [CrossRef]

Lee, Min-Dong Paul, and Michael Lounsbury. 2015. Filtering institutional logics: Community logic variation and differential responses to the institutional complexity of toxic waste. Organization Science 26: 847-66. [CrossRef]

Lehner, Othmar M., and Juha Kansikas. 2013. Pre-paradigmatic status of social entrepreneurship research: A systematic literature review. Journal of Social Entrepreneurship 4: 198-219. [CrossRef]

Leo XIII. 1891. Encyclical Letter: ‘Rerum Novarum' (of Revolutionary Change). Available online: https://www.vatican.va/content/ leo-xiii/en/encyclicals/documents/hf_l-xiii_enc_15051891_rerum-novarum.html (accessed on 30 July 2021).

Lewis, Marianne W. 2000. Exploring paradox: Toward a more comprehensive guide. Academy of Management Review 25: 760-76. [CrossRef]

Lüscher, Lotte S., and Marianne W. Lewis. 2008. Organizational change and managerial sensemaking: Working through paradox. Academy of Management Journal 51: 221-40. [CrossRef]

Magnuson, Norris A. 1977. Salvation in the Slums: Evangelical Social Work, 1865-1920. Metuchen: Scarecrow Press.

McCann, Dennis. 2011. The principle of gratuitousness: Opportunities and challenges for business in «Caritas in Veritate». Journal of Business Ethics 100: 55-66. [CrossRef]

McMullen, Jeffery S., and Benjamin J. Warnick. 2016. Should we require every new venture to be a hybrid organization? Journal of Management Studies 53: 630-62. [CrossRef]

McVea, John F., and Michael J. Naughton. 2021. Enriching social entrepreneurship from the perspective of Catholic Social Teaching. Religions 12: 173. [CrossRef]

Melé, Domènec, and Michael Naughton. 2011. The encyclical-letter "Caritas in Veritate": Ethical challenges for business. Journal of Business Ethics 100: 1-7. [CrossRef] 
Miller, David W. 2003. The Faith at Work Movement: Its Growth, Dynamics, and Future. Ph.D. thesis, Princeton University, Princeton, NJ, USA.

Miller, Toyah L., Matthew G. Grimes, Jeffery S. McMullen, and Timothy J. Vogus. 2012. Venturing for others with heart and head: How compassion encourages social entrepreneurship. Academy of Management Review 37: 616-40. [CrossRef]

Mitzinneck, Björn C., and Marya L. Besharov. 2019. Managing value tensions in collective social entrepreneurship: The role of temporal structural, and collaborative compromise. Journal of Business Ethics 159: 381-400. [CrossRef]

Moberg, David O. 2002. Assessing and measuring spirituality: Confronting dilemmas of universal and particular evaluative criteria. Journal of Adult Development 9: 47-60. [CrossRef]

Mongelli, Luca, Francesco Rullani, Tommaso Ramus, and Tomislav Rimac. 2019. The bright side of hybridity: Exploring how social enterprises manage and leverage their hybrid nature. Journal of Business Ethics 159: 301-5. [CrossRef]

Morita, Tetsuya. 2017. Toward a conceptual framework for religious logics on institutional complexity: A lesson from 'mission drift' in Evangelical Christian social entrepreneurs in Ethiopia. Paper presented at the 6th EMES International Research Conference on Social Enterprise, Liege, Belgium, July 3-6.

Myers, Bryant L. 1999. Walking with the Poor: Principles and Practices of Transformational Development. Maryknoll: Orbis.

Nielsen, R. P., and C. Lockwood. 2018. Varieties of transformational solutions to institutional ethics logic conflicts. Journal of Business Ethics 149: 45-55. [CrossRef]

Ocasio, William. 1997. Towards an attention-based view of the firm. Strategic Management Journal 18: 187-206. [CrossRef]

Oham, Charles. 2015. Case Studies on Faith-Based Social Enterprises: An Oxford University Innovation Partnership Study Visit Programme. Available online: http:/ /www.i3centre.com/wp-content/uploads/2015/10/FBSE-STUDY-Report-Dis.pdf (accessed on 15 February 2016).

Pache, Anne-Claire, and Filipe Santos. 2013. Inside the hybrid organization: Selective coupling as a response to competing institutional logics. Academy of Management Journal 56: 972-1001. [CrossRef]

Roundy, Philip T., Valerie A. Taylor, and W. Randy Evans. 2016. Founded by faith: Social entrepreneurship as a bridge between religion and work. Journal of Ethics and Entrepreneurship 6: 13-37.

Rundle, Steven L. 2014. Does donor support help or hinder business as mission practitioners? An empirical assessment. International Bulletin of Missionary Research 38: 21-26. [CrossRef]

Saebi, Tina, Nicolai J. Foss, and Stefan Linder. 2019. Social entrepreneurship research: Past achievements and future promises. Journal of Management 45: 70-95. [CrossRef]

Santos, Filipe M. 2012. A positive theory of social entrepreneurship. Journal of Business Ethics 111: 335-51. [CrossRef]

Saroglou, V. 2012. Is religion not prosocial at all? Comment on Galen. Psychological Bulletin 138: 907-12. [CrossRef]

Seo, Myeong-Gu, and W. Douglas Creed. 2002. Institutional contradictions, praxis, and institutional change: A dialectical perspective. Academy of Management Review 27: 222-47. [CrossRef]

Smets, Michael, Paula Jarzabkowski, Gary T. Burke, and Paul Spee. 2015. Reinsurance trading in Lloyd's of London: Balancing conflicting-yet-complementary logics in practice. Academy of Management Journal 58: 932-70. [CrossRef]

Smith, Brett R., Jeffery S. McMullen, and Melissa S. Cardon. 2021. Toward a theological turn in entrepreneurship: How religion could enable transformative research in our field. Journal of Business Venturing 36: 1-9. [CrossRef]

Smith, Brett R., Michael J. Conger, Jeffery S. McMullen, and Mitchell J. Neubert. 2019. Why believe? The promise of research on the role of religion in entrepreneurial action. Journal of Business Venturing Insights 11: 1-11. [CrossRef]

Smith, Wendy K., and Marya L. Besharov. 2019. Bowing before dual gods: How structured flexibility sustains organizational hybridity. Administrative Science Quarterly 64: 1-44. [CrossRef]

Smith, Wendy K., Marianne W. Lewis, Paula Jarzabkowski, and Ann Langley. 2017. Paradox in organizational theory. In The Oxford Handbook of Organizational Paradox. Oxford: Oxford University Press, pp. v-viii. [CrossRef]

Smith, Wendy K., Michael Gonin, and Marya L. Besharov. 2013. Managing social-business tensions: A review and research agenda for social enterprise. Business Ethics Quarterly 23: 407-42. [CrossRef]

Soble, Alan. 1989. Eros, Agape, and Philia: Readings in the Philosophy of Love. New York: Paragon House.

Spear, Roger. 2010. Religion and social entrepreneurship. In Values and Opportunities in Social Entrepreneurship. Edited by Kai Hockerts, Johanna Mair and Jeffrey Robinson. London: Palgrave Macmillan, pp. 31-51. [CrossRef]

Spedale, Simona, and Tony J. Watson. 2014. The emergence of entrepreneurial action: At the crossroads between institutional logics and individual life-orientation. International Small Business Journal 32: 759-76. [CrossRef]

Spencer, Liz, Jane Ritchie, Rachael Ormston, William O'Connor, and Matt Barnard. 2014. Analysis: Principles and processes. In Qualitative Research Practice: A Guide for Social Science Students and Researchers, 2nd ed. Edited by Jane Ritchie, Jane Lewis, Carol McNaughton Nicholls and Rachael Ormston. Los Angeles: SAGE, pp. 269-94.

Stake, Robert E. 2006. Multiple Case Study Analysis. New York: Guilford Press.

Stark, Rodney. 1996. A Theory of Religion. New Brunswick: Rutgers University Press.

Stephan, Ute, Malcolm Patterson, Ciara Kelly, and Johanna Mair. 2016. Organizations driving positive social change: A review and an integrative framework of change processes. Journal of Management 42: 1250-81. [CrossRef]

Tan, Wee-Liang, John Williams, and Teck-Meng Tan. 2005. Defining the social in social entrepreneurship: Altruism and entrepreneurship. The International Entrepreneurship and Management Journal 1: 353-65. [CrossRef] 
Tasselli, Stefano. 2019. Love and organization studies: Moving beyond the perspective of avoidance. Organization Studies 40: 1073-88. [CrossRef]

Thornton, Patricia H., and William Ocasio. 1999. Institutional logics and the historical contingency of power in organizations: Executive succession in the higher education publishing industry, 1958-1990. American Journal of Sociology 105: 801-43. [CrossRef]

Thornton, Patricia H., William Ocasio, and Michael Lounsbury. 2012. The Institutional Logics Perspective: A New Approach to Culture, Structure, and Process. Oxford: Oxford University Press. [CrossRef]

Tracey, Paul, Nelson Phillips, and Michael Lounsbury. 2014. Taking religion seriously in the study of organizations. In Religion and Organization Theory. Edited by Paul Tracey, Nelson Phillips and Michael Lounsbury. Bingley: Emerald, pp. 3-21. [CrossRef]

Werner, Andrea. 2008. The influence of Christian identity on SME owner-managers' conceptualisations of business practice. Journal of Business Ethics 82: 449-62. [CrossRef]

Westenholz, Ann. 1993. Paradoxical thinking and change in the frames of reference. Organization Studies 14: 37-58. [CrossRef]

Whittam, Geoffrey, and Kean Birch. 2011. Can the market deliver the goods? A critical review of the social enterprise agenda. In Enterprise, Deprivation and Social Exclusion: The Role of Small Business in Addressing Social and Economic Inequalities. Edited by Alan Southern. New York: Routledge, pp. 239-53. [CrossRef]

Yang, Mayfair Mei-hui. 2000. Putting global capitalism in its place: Economic hybridity, bataille, and ritual expenditure. Current Anthropology 41: 477-509. [CrossRef]

Yin, Robert K. 2014. Case Study Research: Design and Methods, 5th ed. Thousand Oaks: SAGE.

Yinger, J. Milton. 1967. Pluralism, religion, and secularism. Journal for the Scientific Study of Religion 6: 17-28. [CrossRef]

Zahra, Shaker A., Eric Gedajlovic, Donald O. Neubaum, and Joel M. Shulman. 2009. A typology of social entrepreneurs: Motives, search processes and ethical challenges. Journal of Business Venturing 24: 519-32. [CrossRef]

Zhao, Eric Yanfei, and Michael Lounsbury. 2016. An institutional logics approach to social entrepreneurship: Market logic, religious diversity, and resource acquisition by microfinance organizations. Journal of Business Venturing 31: 643-62. [CrossRef] 